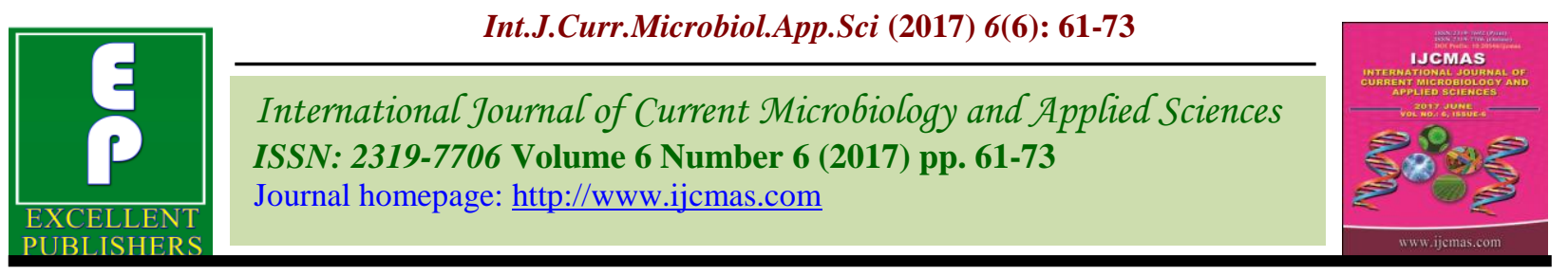

Original Research Article

https://doi.org/10.20546/ijcmas.2017.606.007

\title{
Concept of Heterotic Group and its Exploitation in Hybrid Breeding
}

\author{
Ashok Kumar Meena ${ }^{1 *}$, Deshraj Gurjar ${ }^{2}$, S.S. Patil and Bheru Lal Kumhar ${ }^{3}$ \\ ${ }^{1}$ University of Agriculture Sciences Dharwad, Dharwa- 580005, India \\ ${ }^{2}$ Maharana Pratap University of Agriculture and Technology, Udaipur, India \\ ${ }^{3}$ Agricultural Research Station, Ummedganj, Agriculture University, Kota, India \\ *Corresponding author
}

\begin{abstract}
Keywords
Genetic diversity,

Germplasm,

Heterotic groups

and

heterotic patterns.

Article Info

Accepted:

04 May 2017

Available Online:

10 June 2017 complementary lines for maximizing the outcomes of a hybrid breeding program. Development of hybrid oriented heterotic populations and application of schemes for improving combining ability is an integral part of hybrid breeding in maize and other cross pollinated crops. Broadening the genetic base of heterotic pools is a key to ensure continued genetic gain in hybrid breeding. The selection of parents and breeding strategies for the successful hybrid production will be facilitated by heterotic grouping of parental lines and determination of combining abilities of them. Assigning germplasms into different heterotic groups and patterns is fundamental for exploitation of heterosis for hybrid development. If once heterotic groups and their pattern are identified then large number of hybrid combination can be developed, within short period of time because grouping of lines in different clusters would avoid the development and evaluation of unnecessary hybrids from these heterotic patterns. Our objectives of this review are (i) Review various methods used to assign germplasm into heterotic groups and identify their heterotic pattern in different crops on the basis of experimental evidence supporting them. (ii) Listing out various heterotic groups and heterotic patterns in different crops and (iii) Examine advantages and disadvantages of the concept of heterotic groups and patterns.
\end{abstract}

\section{A B S T R A C T}

Narrow genetic base is one of the most important limiting factors for yield improvement and is a bottleneck in any of the breeding programs. Information on genetic diversity and heterotic groups is very useful in inbred line development and help breeders to utilize their germplasm in a more efficient and consistent manner through exploitation of

\section{Introduction}

The application of heterosis in crop breeding and production is the most important contribution of plant genetics to the development of agricultural technology in the last century (Zhang et al., 1998).The phenomenon of heterosis was defined by Shull (1952) as "the interpretation of increased vigor, size, fruitfulness, speed of development, resistance to disease and to insect pests, or to climatic rigors of any kind manifested by crossbred organisms as compared with corresponding inbreds, as the specific results of unlikeness in the constitution of the uniting parental gametes". For our purposes, we will define heterosis as the difference between the hybrid and the mean of its two parents (Schnell, 1961).

Information on heterotic groupings of germplasm is essential for hybrid breeding 
program. Assigning germplasms into different heterotic groups is fundamental for the maximum exploitation of heterosis for hybrid cultivar development. Similarly, information on genetic diversity is also very important for hybrid breeding and population improvement programs for assessing the level of genetic diversity, characterizing the germplasm and assigning them into different heterotic groups (Reif et al., 2003). For an efficient hybrid breeding program, it is desirable to organize the germplasm into heterotic groups (Reif et al., 2007).

The classification of elite germplasm and inbred lines into different heterotic groups is an important task in any of the breeding program (Hallauer et al., 1998). Introgression of exotic germplasm is often suggested for increasing the genetic differences between opposite heterotic populations with an expected increase in heterotic response (Beck et al., 1991; Vasal et al., 1992a, b; Ron Parra and Hallauer, 1997).

Melchinger and Gumber (1998) defined a heterotic group "as a group of related or unrelated genotypes from the same or different populations, which display similar combining ability and heterotic response when crossed with genotypes from other genetically distinct germplasm groups. By comparison, the term heterotic pattern refers to a specific pair of two heterotic groups, which express high heterosis and consequently high hybrid performance in their cross." The concept of heterotic patterns includes the subdivision of the germplasm available in a hybrid breeding program in at least two divergent populations, which are improved with inter-population selection methods. Heterotic patterns have a strong impact in crop improvement because they predetermine to a large extent the type of germplasm used in a hybrid breeding program over a long period of time (Melchinger and
Gumber, 1998). Heterotic pattern is a key factor for utilizing germplasm to maximize performance of the population crosses and derived hybrids (Eberhart et al., 1995). The development of successful maize (Zea mays L.) hybrids requires establishment of heterotic patterns, defined as the cross between known genotypes that expresses a high level of heterosis (Carena and Hallauer, 2001).

The most exploited heterotic pattern is the cross between Iowa Stiff Stalk Synthetic (BSSS) and Lancaster Sure Crop heterotic groups. Crosses among inbred lines that derive from unrelated heterotic groups are known to have better grain yield performance than those crosses among lines belonging to the same group (Moll et al., 1965; Hallauer et al., 1988; Melchinger, 1999).

Molecular markers have shown to be useful classifying unrelated inbred lines into heterotic groups (Smith et al., 1997; Pejic et al., 1998; Senior et al., 1998; Lu and Bernardo, 2001; Li et al., 2002). Based on this information, the integration of molecular markers in maize-breeding programs can increase their efficiency. Simple sequence repeats (SSR) have been extensively used as genetic markers in eukaryotic genomes (Tautz, 1989). Such markers have large number of advantages over the amplified fragment length polymorphism (AFLP), random amplified polymorphic DNA (RAPD), and restriction fragment length polymorphism (RFLP) markers (Pejic et al., 1998; Senior et al., 1998; Gethi et al., 2002).

Some authors have demonstrated the efficiency of the identification of heterotic groups of maize lines by using molecular procedures such as restriction fragment length polymorphisms (RFLPs) (Ajmone-Marsan et al., 1998; Benchimol et al., 2000; Pinto et al., 2003; Warburton et al., 2005), amplified fragment length polymorphisms (AFLPs) 
(Oliveira et al., 2004; Legesse et al., 2007) and simple sequence repeat (SSR) markers (Reif et al., 2003; Barata and Carena, 2006). An advantage over conventional methods is that few divergent lines are not discriminated, and consequently, heterotic groups are formed that contain genotypes, which unequivocally represent the differences in the allele frequency of the populations. This necessitated a study of heterotic relationships among Iranian maize germplasm. Choukan et al., (2006), using cluster analysis from genetic distance based on SSR makers to evaluate Iranian maize inbred lines reported that the lines could be classified into four preliminary heterotic groups.

\section{Concept of heterotic groups and pattern}

The phenomenon of heterosis was first detected in maize. Shull defined heterosis in 1952 as, "The increased vigour, speed of development, resistance to disease and insect pests, or to climatic rigours of any kind, manifested by crossbred organisms as compared with corresponding inbreds as the specific result of unlikeness in the constitutions of the uniting parental gametes." The term heterotic group refers to "a group of related or unrelated genotypes from the same or different populations, which display similar combining ability and heterotic response when crossed with genotypes from other genetically distinct germplasm groups" (Melchinger and Gumber, 1998). 'Heterotic pattern' refers to a specific pair of 2 heterotic groups that express high heterosis and high hybrid performance in their cross.

\section{Criteria for the identification of new heterotic groups and patterns}

Several criteria have been suggested to choose promising heterotic groups: high mean performance and large genetic variance in the hybrid population in the target region(s), high per se performance and good adaptation of the parent populations, and a higher ratio of the variance due to general ( $\sigma 2$ GCA) versus specifi c combining ability ( $\sigma 2$ SCA) (Melchinger and Gumber, 1998; Reif et al., 2005a). Low inbreeding depression in the source materials for the development of inbreds; and a stable CMS system without deleterious side effects, as well as effective restorers and maintainers, if hybrid breeding is based on cytoplasmic male sterility.

\section{Various methods to develop Heterotic groups}

\section{Pedigree analysis}

The heterotic pattern increases the efficiency of hybrid development, inbred recycling and population improvement. The Reid and Lancaster groups were identified based upon pedigree and geography analysis of inbred lines used in the Corn Belt. Wu (1983) attempted to classify inbred lines into 4 or 5 groups based on pedigree analysis and to predict heterotic patterns used in China.

\section{Quantitative genetic analysis}

Melchinger (1999) reviewed the different approaches to classify and identify heterotic groups. Diallels or factorial designs have been used when the number of populations or groups was small in tropical (Vasal et al., 1999) and temperate corn (Ordas, 1991; Moreno-Gonzaler et al., 1988). Development of hybrid oriented heterotic populations and application of schemes for improving combining ability is an integral part of hybrid breeding in maize and other cross pollinated crops (Hallauer and Miranda, 1981). Basis of grouping the germplasms into different heterotic groups was specific combining ability (SCA) effects for grain yield (Gurung et al., 2009, Fan et al., 2009). Cluster analysis based on SCA can be used to classify inbred lines into heterotic groups. Fourteen maize 
inbred lines, used in maize breeding programs in Iran, were crossed in a diallel mating design for investigation of combining ability of genotypes for grain yield and to determine heterotic patterns among germplasm sources, using both, the Griffing's method and the biplot approach for diallel analysis (Bidhendi et al., 2012).

\section{Geographical isolation inference}

The geographical origin of the two populations contributed to the high grain yield of the cross (Moll et al., 1962, 1965; Reif et al., 2005b). Heterotic rice hybrids are generally derived from distant parents by geographic origin or different ecotypes (Yuan 1977; Lin and Yuan 1980). In the earlier stage of hybrid rice development in China two heterotic groups that is early season indica from southern China and midor late-season indica from Southeast Asia were identified for three-line hybrid rice based on wild abortive (WA) male sterile cytoplasm (Yuan 1977).

\section{Use of molecular markers}

Genotyping and cluster analysis of extracted genotypic DNA from the mutants and respective parents from their young leaves (1 to 2 weeks after seed germination), using the Cetyltrimethy lammonium bromide (CTAB) method (Hoisington et al., 1994). These genotypes were further genotyped using twenty one Simple Sequence Repeats (SSR) markers on GenBank data base ( $\mathrm{Yu}$ et al., 2000). Genetic diversity studies determine the variation among individuals or groups of individuals using a specific method or combination of methods to analyze multivariate datasets (Mohammadi and Prasanna, 2003). Diverse datasets have been used to analyze genetic diversity in crop plants, among them which are pedigree data, morphological data (Badu-Apraku et al., 2006), genetic parameter estimates (Camussi et al., 1985), heterosis data (Badu-Apraku et al., 2013a, b), biochemical data, and molecular marker data (Melchinger et al., 1991; Betran et al., 2003; Mohammadi and Prasanna 2003). Molecular marker data provide a more reliable differentiation of genotypes (Mohammadi and Prasanna 2003), since these data are less affected by environmental effects. Molecular marker data classified a set of germplasm based on genetic similarities, however Melchinger and Gumber (1998) emphasized that it has been challenging to predict heterotic relationships based on these data. Additionally, researchers agreed that field experiments are still needed to validate groupings of germplasm based on molecular marker data (Melchinger and Gumber, 1998; Barata and Carena, 2006)

We concluded that the relationships between the populations obtained by SSR analyses are in excellent agreement with pedigree information. SSR markers are a valuable complementation to field trials for identifying heterotic groups and can be used to introgress exotic germplasm systematically (Reif et al., 2003; Yuan et al., 2002 and Aguiar et al., 2008).

\section{Various strategy for establishment of heterotic patterns}

Two well-known strategy for the establishment of heterotic pattern by Cress (1967) (Cress strategy) and another one by Melchingner and Gumber (Melchingner and Gumber Strategy).

The decision which of both strategies is superior it depends on several factors such as (i) the genetic basis of heterosis, (ii) the applied selection intensities for QTL, or (iii) the importance of favorable linkages. Further research is required incorporating recent advances on the genetic architecture of quantitative traits and on the genetic basis of 
heterosis to develop optimal procedures for establishing and maintaining heterotic patterns.

A very new method to develop heterotic groups is suggested by Patil (Unpublished method)

This basic formula: HF1 $=\Sigma$ dy2 explains how performance (heterosis) of hybrid depends on genetic diversity and extent of dominance existing at different yield influencing loci (Falconer 1981). Development of hybrid oriented heterotic populations and application of schemes for improving combining ability is an integral part of hybrid breeding in maize and other cross pollinated crops (Hallauer and Miranda, 1981).

In the recent years the concept of developing heterotic populations is put to test in selfpollinated crops like cotton, segregating populations based on diverse pairs of genotypes can be the ideal base material required for implementing procedures like reciprocal selection for improving combining ability (Patil and Patil, 2003; Patil et al., 2011)

Population improvement schemes have led to the development of maize lines with improved combining ability resulting in the isolation of superior hybrid combinations. The recurrent selection procedures are also suggested for often cross pollinated crops by considering cotton as an example (Miller and Rawlings, 1967) and in sorghum (Dogget and Eberhart, 1968) by utilizing male sterility system. Considering the success achieved in commercial exploitation of heterosis in cotton, sorghum, rice and such other often cross pollinated or self-pollinated crops, it is possible to visualize that such schemes of improving combining ability by following the recurrent selection schemes can be very well followed in these crops, with suitable modification in procedure in tune with the mating system of these crops (Patil and Patil, 2003).

\section{Advantages and disadvantages of heterotic groups and heterotic patterns}

Intergroup hybrids out yielded the respective intra-group hybrids by $21 \%$ in Reid Yellow Dent $\times$ Lancaster Sure Crop crosses (Dudley et al., 1991) and by 16\% in Flint Dent crosses (Dhillon et al., 1993). These results clearly indicate that grouping of germplasm in divergent pools is advantageous to maximize the expected heterosis. Cress (1967) evaluated in a simulation study inter- population improvement methods. He pointed out that the maximum genetic potential could not be reached in a breeding system with two strictly separated groups if the best alleles are present in only one of the two populations assuming a degree of dominance smaller than one.

However, it is questionable that maximum yield potential is an appropriated criterion to evaluate selection strategies. Under the assumption that a large number of QTL are underlying a complex trait such as grain yield, it is of upmost importance to increase the probability to combine at different QTL as many positive alleles as possible. Applying the concept of heterotic patterns enables breeders to simultaneously select on two inbred lines, which are combined in a single hybrid. An increased divergence between two populations of a heterotic pattern increases the probability to complementary select for favorable alleles at different loci. Melchinger et al., (1987) emphasized the importance of the variances due to general ( $\sigma 2$ GCA) and specific combining ability ( $\sigma 2$ SCA) and their ratio for predicting hybrid performance. 
Table.1 Various heterotic groups and heterotic patterns in different crops

\begin{tabular}{|c|c|c|c|c|}
\hline Crop & Heterotic Group & Heteroic pattern & Country & Reference \\
\hline 1. Maize & $\begin{array}{l}\text { U.S. dent lines, European } \\
\text { flint lines }\end{array}$ & U.S. dent lines X European flint lines & Europe & Schnell et al., 1992 \\
\hline & $\begin{array}{l}\text { female group Stiff Stalk } \\
\text { (SS) and the male group is } \\
\text { designated Non-Stiff Stalk } \\
(\mathrm{NSS})\end{array}$ & $\begin{array}{l}\text { Stiff Stalk (SS) X Non-Stiff Stalk } \\
\text { (NSS) }\end{array}$ & $\begin{array}{l}\text { U.S. Corn Belt } \\
\text { and Canada }\end{array}$ & Duvick et al., 2004 \\
\hline & $\begin{array}{l}\text { Tang sipingtou and Luda } \\
\text { honggu } \\
\text { Lancaster Sure Crop (LSC), } \\
\text { Reid Yellow dent (RYD) }\end{array}$ & $\begin{array}{l}\text { Tang sipingtou X Luda honggu } \\
\text { germplasm, domestic } \times \text { LSC, } \\
\text { domestic } \times \text { PN, Dom } \times \text { Lan or Dom } \\
\times \text { Reid. Luda Red Cob } \times \text { Lan }\end{array}$ & USA, China & Li et al., 2002, 2004. \\
\hline & Suawan, Reid, Non Reid & $\begin{array}{l}\text { Suawan X Reid, Suawan X Non Reid, } \\
\text { Reid X Non Reid }\end{array}$ & China & Fan et al., 2013 \\
\hline & $\begin{array}{l}\text { Tuxpeno combines well } \\
\text { with Cuban Flint, Coastal } \\
\text { Tropical Flint (Caribbean } \\
\text { Flint), Tuson, ETO, Perla } \\
\text { and Chandelle }\end{array}$ & $\begin{array}{l}\text { Tuxpeno combines well with Cuban } \\
\text { Flint, Coastal Tropical Flint } \\
\text { (Caribbean Flint), Tuson, and ETO } \\
\text { Cuban Flint combines well with } \\
\text { Tuxpeno, Tuson, Coastal Tropical } \\
\text { Flint, and Perla. } \\
\text { Coastal Tropical Flint combines well } \\
\text { with Tuxpeno, Cuban Flint, and } \\
\text { Chandelle }\end{array}$ & China & $\begin{array}{l}\text { Wellhausen, } 1978 \\
\text { Goodman, } 1985 \\
\text { Vasal et al., } 1999\end{array}$ \\
\hline 2. Rice & $\begin{array}{l}\text { Early season indica from } \\
\text { southern China and mid or } \\
\text { late-season indica from } \\
\text { Southeast Asia }\end{array}$ & $\begin{array}{l}\text { Early season indica from southern } \\
\text { China X mid or late-season indica } \\
\text { from Southeast Asia }\end{array}$ & China & Yuan, 1977 \\
\hline 3. Rye & The "Petkus" and "Carsten", & The "Petkus" X "Carsten", & Europe & Hepting, 1978 \\
\hline $\begin{array}{l}\text { 4. Faba } \\
\text { bean }\end{array}$ & $\begin{array}{l}\text { "Minor", "Major", and } \\
\text { "Mediterranean" }\end{array}$ & $\begin{array}{l}\text { "Minor" X “Major", } \\
\text { "Minor" X “Mediterranean", } \\
\text { "Major", X X"Mediterranean" }\end{array}$ & $\begin{array}{l}\text { Europe, } \\
\text { Germany }\end{array}$ & Link et al., 2006 \\
\hline $\begin{array}{l}\text { 5. Rape } \\
\text { seed }\end{array}$ & $\begin{array}{l}\text { Asian, European winter- } \\
\text { type and Canadian and } \\
\text { European spring-type }\end{array}$ & $\begin{array}{l}\text { Asian, European winter-type } \mathrm{X} \\
\text { Canadian and European spring-type }\end{array}$ & $\begin{array}{l}\text { Canada } \\
\text { Europe }\end{array}$ & Qian et al., 2009 \\
\hline 6. Millets & Tiouma, Souna3 & Tiouma $\times$ Souna 3 & Iran, India & $\begin{array}{l}\text { Issoufou Kassari Ango, } \\
\text { Inran, Bettina } \\
\text { Haussmann, ICRISAT }\end{array}$ \\
\hline
\end{tabular}

\begin{tabular}{l}
\hline MELCHINGER and GUMBER (1998) \\
\hline MELCHINGER and GUMBER (1998) recommended the \\
following criteria for the identification of new patterns: \\
(i) high mean performance and large genetic variance in \\
the hybrid population; (ii) high per se performance and \\
good adaptation of the parent populations to the target \\
environment; and (iii) low inbreeding depression, if \\
hybrids are produced from inbreds. In practice, the \\
choice of heterotic patterns is mainly based on the \\
performance of the corresponding hybrid population.
\end{tabular}

\section{CRESS (1967)}

CRESS (1967) suggested, based on results of a simulation study, that all genetic material entered into a long-term program of inter-population selection should be combined into one synthetic population (Fig. 3). Any subsequent populations required would be obtained by sampling this synthetic. However, the results reported by CRESS (1967) were based on a rather simple genetic model assuming (i) a low number of quantitative trait loci (QTL), (ii) absence of linkage between the QTL, (iii) two alleles per QTL, and (iv) no epistasis. In contrast to the suggestions of CRESS (1967). 
Germplasm available:

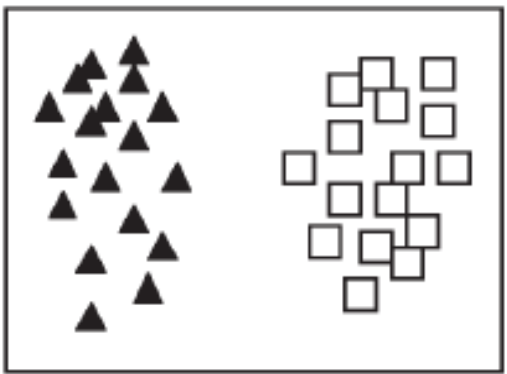

Two-dimensional relationship reflecting dominance-associated distances for yield (HANSON and MOLL, 1986)

Strategy MELCHINGER and GUMBER (1998):

\section{Group germplasm based on its cross performance}

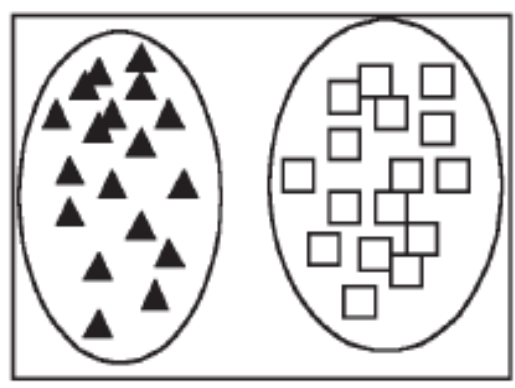

2. Identified groups are the two heterotic groups

Heterotic groups:
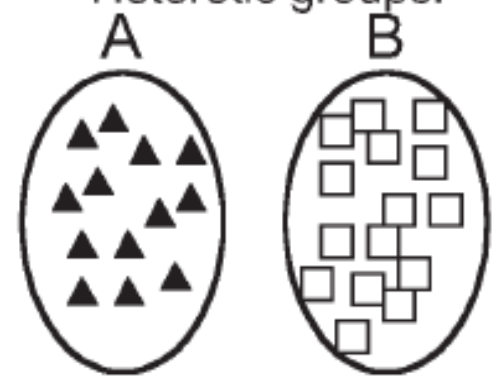

Strategy CRESS (1967):

1. Combine germplasm in one synthetic; random mating

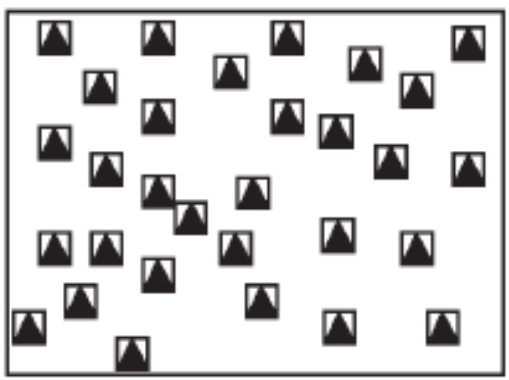

2. Randomly create two populations used as heterotic groups

Heterotic groups
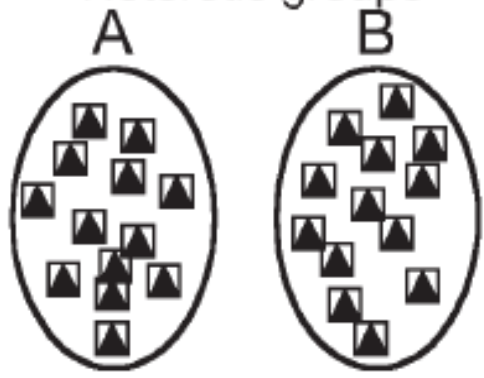


\title{
Steps Involved In Development Of Heterotic Groups
}

\author{
Phenotypic characterization and diversity studies \\ $\sqrt{3}$ \\ Studies on Plant types and Physiological process \\ $\sqrt{ }$ \\ Identifying Ideal Plant types for high productivity \\ $\sqrt{ }$ \\ Studies on hybrid performance and understanding of \\ traits leading to heterosis \\ $\sqrt{ }$ \\ Development Heterotic groups \\ $\sqrt{7}$ \\ Exploitation of heterotic groups through Reciprocal selection \\ for combining ability and other methods \\ $\sqrt{ }$ \\ Broad based populations of each heterotic group
}

One hypothesis is that the establishment of heterotic pools leads to a predominance of $\sigma 2$ GCA over $\sigma 2$ SCA, and thus early testing becomes more effective. Furthermore, superior hybrids can be identified and selected mainly based on their prediction from GCA effects. Experimental data of estimates of the magnitude and expected ratio $\sigma 2 \mathrm{SCA}: \sigma 2 \mathrm{GCA}$ of for inter-pool compared with intra-pool crosses are limited and mostly based on few factorial combinations. First results have been presented in maize by MELCHINGER and GUMBER (1998). A lower ratio of $\sigma 2$ SCA: $\sigma 2$ GCA was found in inter- than in intragroup crosses indicating that the concept of heterotic patterns effectively supports the selection of superior hybrids. These findings are in agreement with theoretical results indicating that inter-group crosses have smaller $\sigma 2$ SCA and $\sigma 2$ SCA: $\sigma 2$ GCA ratios than intra-group crosses (MELCHINGER, 1996, unpublished results).

Objectives of heterotic groups and heterotic patterns development

To get higher mean heterosis and hybrid performance.

To reduce the specific combining ability (SCA) variance and a lower ratio of SCA to general combining ability (GCA) variance.

Assigning lines to heterotic groups would avoid the development and evaluation of crosses that should be discarded, allowing maximum heterosis to be exploited by crossing inbred lines belonging to different heterotic groups.

To save the time of hybrid development. 
Utilize new germplasm to broaden the genetic background of hybrid.

In conclusion, information on genetic diversity and heterotic groups is very useful in hybrid development and help breeders to utilize their germplasm in a more efficient and consistent manner. If once heterotic groups and their pattern are identified then large number of hybrid combination can be developed, within short period of time because grouping of lines in different heterotic groups would avoid the development and evaluation of unnecessary hybrids from these heterotic groups. Good heterotic group classification method can be defined as one which allow inter-heterotic group crosses to produce more superior hybrids than the within- group crosses. Heterotic patterns have a strong impact in crop improvement because they predetermine to a large extent the type of germplasm used in a hybrid breeding program over a long period of time.

\section{References}

Aguiar, C. G., Schuster, Amaral Júnior A. T., Scapim, C. A., and Vieira E. S. N., (2008). Heterotic groups in tropical maize germplasm by test crosses and simple sequence repeat markers. Genet. Mol. Res. 7 (4): 1233-1244.

Ajmone-Marsan, P., Castiglioni, P., Fusari, F., and Kuiper, M., (1998). Genetic diversity and its relationship to hybrid performance in maize as revealed by RFLP and AFLP markers. Theor. Appl. Genet. 96: 219-227.

Badu-Apraku, B., Menkir, A., Fakorede, MAB, Lum, A.F. and Obeng-Antwi, K. (2006). Multivariate analyses of the genetic diversity of forty-seven Striga resistant tropical early maturing maize inbred lines. Maydica, 51:551-559.

Badu-Apraku, B., Oyekunle, M., Akinwale, R.O. and Aderounmu, M. (2013a).
Combining ability and genetic diversity of extraearly white maize inbreds under stress and nonstress environments. Crop Sci, 53:9-26.

Badu-Apraku, B., Oyekunle, M., Fakorede, MAB, Vroh, I., Akinwale, R.O. and Aderounmu, M. (2013b). Combining ability, heterotic patterns and genetic diversity of extra-early yellow inbreds under contrasting environments. Euphytica. doi: 10.1007/s10681-0130876-4.

Barata, C. and Carena, M.J. (2006). Classification of North Dakota maize inbred lines into heterotic groups based on molecular and testcross data. Euphytica 151: 339-349.

Beck, D.L., Vasal, S.K. and Crossa, J. (1991). Heterosis and combining ability among subtropical and temperate intermediatematurity maize germplasm. Crop Sci., 31:68-73.

Benchimol, L.L., Souza, C.L., Garcia, AAF and Kono, PMS (2000). Genetic diversity in tropical maize inbred lines: heterotic group assignment and hybrid performance determined by RFLP markers. Plant Breed. 119: 491-496.

Betran, F.J., Ribaut, J.M., Beck, D. and de Leon D.G. (2003) Genetic diversity, specific combining ability, and heterosis in tropical maize under stress and nonstress environments. Crop Sci. 43:797-806.

Bidhendi, M. Z., Choukan, R., Darvish, F., Mostafavi, K. and Majidi, E., 2012, Classifying of Maize Inbred Lines into Heterotic Groups using Diallel Analysis. World Aca of Sci, Engi and Tech. 6: 0725.

Camussi, A., Ottaviano, E., Calinski, T. and Kaczmarek, Z. (1985) Genetic distances based on quantitative traits. Genetics 111:945-962.

Carena, M.J. and Hallauer, A.R. (2001a) Expression of heterosis inLeaming and Midland Corn Belt Dent populations. J Iowa Acad Sci 108:73-78. 
Carena, M.J. and Hallauer, A.R. (2001b) Response to inbred progeny selection in Leaming and Midland Yellow Dent maize populations. Maydica 46:1-10.

Choukan, R., Hossainzadeh, A., Ghannadha, M.R., Warburton, M.L., Talei, A.R. and Mohammadi, S. A. (2006) Use of SSR data to determine relationships and potential heterotic groupings within medium to late maturing Iranian maize inbred lines. Field Crops Research, vol. 95, pp. 212-222.

Cress, C.E. (1966) Heterosis of the hybrid related to gene-frequency differences between two populations. Genetics 53:269-274.

Dhillon, B.S., Boppenmaier, J., Pollmer, W.G., Herrmann, R.G. and Melchinger A.E. (1993) Relationship of restriction fragment length polymorphisms among European maize inbreds with ear dry matter yield of their hybrids. Maydica 38: 245-248.

Dogget H, Eberhart (1968) recurrent selection in sorghum. Crop Sci., 8: 119-121.

Dudley J.W., Saghai-Maroof, M.A. and Rufener, G.K. (1991) Molecular markers and grouping of parents in a maize breeding program. Crop Sci. 31: 718-723.

Duvick, D.N., Smith, J.S.C. and Cooper, M. (2004) Long-term selection in a commercial hybrid maize breeding program. Plant Breed. Rev. 24: 109-151.

Eberhart, S.A., Salhuana, W., Sevilla, W.R. and Taba, S. (1995). Principles for tropical maize breeding. Maydica, 40: 339-355.

Falconer, DS. 1981. Introduction of Quantitative Genetics. Longman Inc. Ltd., New York.

Fan, X.M., Zhan, Y.M., Hao, W.H., Chen, H.M., Tan, J., Xu, C.X., Han, X.L., Luo, L.M. and Kang, M.S. (2009) Classifying maize inbred lines into heterotic groups using a factorial mating design. Agron $\mathbf{J}$ 101:106-112.

Gethi, J.G., Labate, J.A., Lamkey, K.R., Smith, M.E. and Kresovich, S. (2002)
SSR variation in important U.S. maize inbred lines. Crop Sci 42:951-957.

Goodman, M.M. (1985) Exotic germplasm: Status, prospects and remedies. Iowa State J. Res. 59: 494-527.

Goodman, M.M. and Stuber, C.W. (1983) Races of maize. VI. Isozyme variation among races of maize in Bolivia. Maydica 28:169-187.

Gurung, D.B., George, L.C. And Delacruz, Q. D. (2009) Determination of Heterotic Groups in Nepalese Yellow Maiz Populations. Nepal Jour of Sci and Tech. 10:1-8.

Hallauer AR, RusselWA, Lamkey KR (1988) Corn breeding. In: Sprague GF, Dudley JW (ed.) Corn and corn improvement, 3rd ed. Agron. Monogr. 18. ASA, CSSA\&SSSA, Madison, WI.

Hallauer, A.R. (1999) temperate maize and heterosis. In: Coors JG, Pandey S (ed.) the genetics and exploitation of heterosis in crops. ASA, CSSA \& SSSA, Madison, WI, pp 353-361.

Hallauer, A.R. and Miranda, J.B. (1981) Quantitative genetics in maizebreeding. Iowa State Univ. Press, Ames, USA.

Hallauer, A.R. and Miranda, J.B. (1981) Quantitative genetics in maize breeding. Iowa State University Press, Ames, pp. 267-298.

Hanson, W.D. and Moll, R.H. (1986) an analysis of changes in dominance associated gene effects under intrapopulation and interpopulation selection in maize. Crop Sci. 26: 268273.

Haullauer, A.R., Russell, W.A. and Lamkey, K.R. (1998) Corn breeding. In:Corn and corn improvement. 3rd edition. (Eds. G.F. sprange and J.W. Dudley) Agron. Monogr.18. Madison, WI. ASA, CSSA and SSSA, 677 South Segoe Road, Madison, WI, 53711, USA, pp. 463564.

Hepting, L. (1978) Analyse eines 7x7Sortendiallels zur Ermittlung geeigneten Ausgangsmaterials fu“ $r$ die 
Hybridzu“"chtung bei Roggen. Z Pflanzenzu chtung 80:188-197.

Hoisington, D., Khairallah, M. and Gonzalezde- Leon, D. (1994). Laboratory Protocols: CIMMYT Applied Molecular genetics Laboratory. Mexico City, Mexico: CIMMYT.

Legesse, B.W., Myburg, A.A., Pixley, K.V., Twumasi-Afriyie, S. (2007). Relationship between hybrid performance and AFLP based genetic distance in highland maize inbred lines. Euphytica 162: 313-323.

Li Y., Du, J., Wang, T., Shi, Y., Song, Y. and Jia J. (2002) Genetic diversity and relationships among Chinese maize inbred lines revealed by SSR markers. Maydica 47: 93-101.

Li Y., Shi, Y., Song, Y., Du, J., Tuberosa, R. and Wang, T. (2004) Analysis of genetic diversity in maize inbred lines based on AFLP markers. Maydica 49: 89-95.

Lin, S.C. and Yuan, L.P. (1980) Hybrid rice breeding in China. In: Innovative approaches to rice breeding. IRRI, Philippines, pp 35-51.

Link, W., Schill, B., Barbera, A.C. and Melchinger, A.E. (2006) Comparison of intra- and inter- pool crosses in faba beans (Vicia faba L.). I. Hybrid performance and heterosis in Mediterranean and German environments. Pla Bree. 115(5):352 360.

Liu, K., Goodman, M.M., Muse, S., Smith, S.C., Buckler, E. and Doebley, J. (2003) Genetic structure and diversity among maize inbred lines as inferred from DNA microsatellites. Genetics 165:2117-2128.

Lu, H. and Bernardo, R. (2001) Molecular marker diversity among current and historical maize inbreds. Theor Appl Genet 103:613-617.

Melchinger, A.E. (1987) Optimum prediction of three-way crosses from single crosses from single crosses in maize (Zea mays L.). Theor. Appl. Genet. 74: 339-345.
Melchinger, A.E. (1999) Genetic diversity and heterosis. In: Coors JG, Pandey S (ed) The genetics and exploitation of heterosis in crops. ASA, CSSA \& SSSA, Madison, WI.

Melchinger, A.E. and Gumber, R.K. (1998) Overview of heterosis and heterotic groups in agronomic crops. pp. 29-44. In: K.R. Lamkey, J.E. Staub (Eds.), Concepts and Breeding of Heterosis in Crop Plants. CSSA, Madison, WI.

Melchinger, A.E., Messmer, M.M., Lee, M., Woodman, W.L. and Lamkey, K.R. (1991) Diversity and relationships among U.S. maize inbreds revealed by restriction fragment length polymorphism. Crop Sci 31:669-678.

Miller, P.A. Rawlings (1967) Selection for increased lint yield and correlated responses in upland cotton. Crop Sci 7: 637-640.

Mohammadi, S.A. and Prasanna, B.M. (2003) Analysis of genetic diversity in crop plants-salient statistical tools and considerations. Crop Sci 43:1235-1248.

Moll, R.H., Lonnquist, J.H., Velez, F.J and Johnson, C. (1965) the relationship of heterosis and genetic divergence in maize. Genetics 52:139-144.

Moll, R.H., Salhuana, W.S. and Robinson, H.F. (1962) Heterosis and genetic diversity in variety crosses of maize. Crop Sci. 2: 197-198.

Moreno-Gonzalez, J. (1988). Diallel crossing system in sets of flint and dent inbred lines of maize (Zea mays L.). Maydica 133: 37-49.

Oliveira, K.M., Laborda, P.R., Garcia, AAF, Paterniani, MEAG (2004). Evaluating genetic relationships between tropical maize inbred lines by means of AFLP profiling. Hereditas, 140: 24-33.

Ordas, A. 1991. Heterosis in crosses between American and Spanish populations of maize. Crop Science 31:931-935.

Patil, S.S. and Patil, S.A. (2003) Role of improving combining ability in increasing performance of cotton hybrids. Third World Cotton Research 
Conference, 9-13 March 2003, held at Cape Town South Africa, pp. 234-238.

Patil, S.S., Ramakrishna, V., Manjula, S.M., Swati, P., Ranganatha, H.M., Kencharaddi, H.G. and Deepakbabu, H., (2011) Deploying reciprocal selection for combining ability for improving performance of hybrids in cotton $(G$. hirsutum). Indian J. Genet., 71(2): 180184.

Pejic, I., Ajmone-Marsan, P., Morgante, M., Kozumplick, V., Castiglioni, P., Taramino, G., and Motto, M. (1998) Comparative analysis of genetic similarity among maize inbred lines detected by RFLPs, RAPDs, SSRs and AFLPs. Theor Appl Genet 97:12481255.

Pinto, RMC, Souza CL Jr, Carlini-Garcia, L.A., Garcia, AAF (2003) Comparison between molecular markers and diallel crosses in the assignment of maize lines to heterotic groups. Maydica 48: 63-73.

Project 'Mobilizing Regional Diversity' \& PROMISO - Project Millet and Sorghum, First fruits from heterotic grouping of millets from West Africa. Successful crossing of Tiouma $\times$ Souna3 in Niger Issoufou KassarI Ango, Inran and Bettina Haussmann, ICRISAT.

Qian, W., Sass, O., Meng, J., Li, M., Frauen, M. and Jung, C. (2007) Heterotic patterns in rapeseed (Brassica napus L.): I. Crosses between spring and Chinese semi-winter lines. Theor. Appl. Genet., 115: 27-34.

Reif, J.C., Gumpert, F.M. Fischer, S. and Melchinger, A.E. (2007) Impact of interpopulation divergence on additive and dominance variance in hybrid populations. Genetics 176:1931-1934.

Reif, J.C., Hallauer, A.R. and Melchinger, A.E. (2005a) Heterosis and heterotic pattern in maize. Maydica 50:215-223.

Reif, J.C., Hamrit, Heckenberger, S.M., Schipprack, W., Bohn, M. and Melchinger, A.E. (2005b) Trends in genetic diversity among European maize cultivars and their parental components during the past 50 years. Theor. Appl. Genet. 111: 838-845.

Reif, J.C, Melchinger, A.E., Xia, X.C., Warburton, M.L., Hoisington, D.A., Vasal, S.K., Srinivasan, G., Bohn M. and Frisch, M. (2003) Genetic distance based on simple sequence repeats and heterosis in tropical maize populations. Crop science 43(4):1275-1282.

Ron, P.J. and Hallauer, A.R. (1997) Utilization of exotic maize germplasm. Plant Breed Rev 14:165-187.

Schnell F.W. (1961) Heterosis and inbreeding effect. Schriftenreihe des Max-PlanckInstituts für Tierzucht und Tierernährung pp. 251-272.

Schnell F.W., Cockerham, C.C. (1992) Multiplicative vs. arbitrary gene action in heterosis. Genetics 131: 461-469.

Senior, M.L., Murphy, J.P., Goodman, M.M. and Stuber, C.W. (1998) Utility of SSRs for determining genetic similarities and relationship in maize using agarose gel system. Crop Sci 38:1088- 1098.

Shull, G.H. (1952) Beginnings of the heterosis concept. pp. 14- 48. In: J.W. Gowen (Ed.), Heterosis. Iowa State College Press, Ames, IA.

Smith, JSC, Chin, ECL, Shu, H., Smith, O.S., Wall, S.J., Senior, M.L., Mitchell, S.E., Kresovich, S. and Ziegle, J. (1997) an evaluation of the utility of SSR loci as molecular markers in maize (Zea mays L.): comparisons with data from RFLPs and pedigree. Theory Appl Genet 95:163-173.

Tautz, D. (1989) hyper variability of simple sequences as a general source of polymorphic DNA markers. Nucleic Acid Res 17:6463-6471.

Vasal S.K., Cordova, H.S. Pandey, S. Srinivasan, G. (1999) Tropical maize and heterosis. pp. 363-373. In: J.G. Coors, S. Pandey (Eds.), the Genetics and Exploitation of Heterosis in Crops. ASA, CSSA, SSSA, Madison, WI.

Vasal SK, Srinivasan G, Crossa J, Beck DL (1992a) Heterosis and combining ability 
of CIMMYT's subtropical and temperate early maturity maize germplasm. Crop Sci 32:884-890.

Vasal, S.K. (1999) Quality protein maize story. In: Proceedings of Workshop on Improving Human Nutrition through Agriculture - The Role of International Agricultural Research. Manila, the Philippines: IRRI.

Vasal, S.K. and Srinivasan, G., Beck, D.L., Crossa, J., Pandey, S. and Leon, C de (1992b) Heterosis and combining ability of CIMMYT's tropical late white maize germplasm. Maydica 37:217-223.

Vasal, S.K. challenges, prospects and priority areas. In: Proc. Seventh Asian Regional Maize Workshop pp. 474-481.

Vasal, S.K., Cordova, H.S., Pandey, S. and Srinivasan, G. (1999) Tropical maize and heterosis. Chapter 34. In: Coors JG, Pandey S (eds).

Warburton, M.L., Ribaut, J.M., Franco, J. and Crossa, J. (2005). Genetic

\section{How to cite this article:}

Ashok Kumar Meena, Deshraj Gurjar, S.S. Patil and Bheru Lal Kumhar. 2017. Concept of Heterotic Group and its Exploitation in Hybrid Breeding. Int.J.Curr.Microbiol.App.Sci. 6(6): 61-73. doi: https://doi.org/10.20546/ijcmas.2017.606.007 characterization of 218 elite CIMMYT maize inbred lines using RFLP markers. Euphytica 142: 97-106.

Wellhausen, E.J. (1978) recent developments in maize breeding in the tropics. In: Walden DB (ed) Maize breeding and genetics.

Wu, J.F. (1983). Scientia Agricultura Sinica 16(2): $1-8$.

Yu, K., Park, J., Poysa, V. and Gepts, V. (2000). Integration of Simple Sequence Repeat (SSR) markers into a molecular linkage map of common bean. The Journal of Heredity 9: 429 - 433.

Yuan, L.P. (1977) Practice and theory of breeding hybrid rice. Sci Agric Sin 10(1):27-31.

Zhang, S.H. (1998) Maize production and research for the next century in China: Progress. 